\title{
The Role of Student Counselling for Widening Participation of Underrepresented Groups in Higher Education
}

\author{
Janine Wulz, Marita Gasteiger and Johannes Ruland
}

\section{Social Dimension as a Crucial Element of the Bologna Process}

Higher education was available only to a small proportion of the population for a long time. While in the 1960s higher education participation was around $10 \%$ in most European countries, today raising the proportion of graduates between 30 and 34 years to at least $40 \%$ is an European target (European Commission 2014) and the importance of higher education for economic revival and social cohesion is underlined in many European documents. Recently we can observe higher education following different, even contrary approaches. We notice an increasing commodification of higher education with a focus on competition of European graduates in worldwide economy rather than its social benefits. At the same time, higher education is more and more acknowledged as a means for fostering social mobility and cohesion, also because of high rates of youth unemployment and widening levels of inequality (Riddell and Weedon 2014).

The social dimension of higher education became an important topic in European higher education policies since the beginning of the 21 st century: it was mentioned in different Communiqués following the European Ministerial Conferences, and it is often seen as part of the so-called third mission of universities, considering higher education having a role in society aside teaching and research.

\footnotetext{
J. Wulz $(\bowtie)$

3s Research and Consulting, Vienna, Austria

e-mail:wulz@3s.co.at

M. Gasteiger · J. Ruland

Austrian Students' Union, Graz, Austria

e-mail: marita.gasteiger@oeh.ac.at

J. Ruland

e-mail: johannes.ruland@oeh.ac.at

(C) The Author(s) 2018
}

A. Curaj et al. (eds.), European Higher Education Area: The Impact of Past and Future Policies, https://doi.org/10.1007/978-3-319-77407-7_14 
Social dimension was mentioned in the Prague Communiqué in 2001 for the first time; in 2007 the London Communiqué reaffirms "the importance of students being able to complete their studies without obstacles related to their social and economic background" (London Communiqué 2007). Later on, one of the goals the participants in the Ministerial Conference in 2015 in Yerevan agreed on was making the higher education system more inclusive and therefore widening participation in higher education: "We will enhance the social dimension of higher education, improve gender balance and widen opportunities for access and completion, including international mobility for students from disadvantaged backgrounds." (Yerevan Communiqué 2015). This aim shows already the most common interpretation of social dimension, which is that "a state of participative equity should be attained in European higher education" (Hauschildt et al. 2015). Following the idea of widening access and developing a more inclusive higher education system, underrepresented groups have been in the focus of policies since.

The importance of the issue of social dimension in higher education was raised by the European Students Union for a long time (Vukasovic 2017). During the economic crisis followed by growing numbers of unemployed youth, other stakeholder organisations, such as the European University Association (EUA) and Education International (EI) promoted stronger advocacy for underrepresented groups in higher education and a more inclusive higher education system. Whereas there is a general consensus within all the mentioned Communiqués about social dimension, the stakeholder organizations' approaches were very different in the beginning. While EUA focused mainly on the equity in mobility programmes, at least until 2003, ESU underlined the need to reduce financial obstacles already in its Goteborg Declaration in 2001 (Vukasovic 2017).

Although the social dimension of higher education has been a topic of discussion for more than 15 years now, student population is still not very diverse in most European countries and disadvantaged groups, such as disabled students, students from lower socio-economic backgrounds or those with care obligations are still underrepresented in higher education (EACEA 2015). According to the European Students Union report "Bologna with student eyes", social dimension has only a "more or less high priority" in eight out of 36 countries. And even in countries with a high priority, no major progress has been made so far. The implementation of national access plans is one of the strategies recently developed in many countries, focusing on identifying target groups, developing measures at national and institutional level as well as monitoring the implementation process and its impact (ESU 2015). The measures developed in many countries differ, but can be summarised in the following two different approaches. There are measures developed aiming for widening participation in higher education by general approaches with benefits for the entire student population, and measures put in place to widen participation by the implementation of specific measures for underrepresented target groups. Nevertheless, the 2015 Bologna Process Implementation Report states there is a thin line between those two groups (European Commission/EACEA/Eurydice 2015). 
In this paper we focus on student counselling provided by students' unions as one of the most common measures student unions deliver to empower prospective students and underrepresented groups: What type of counselling offers do students' unions have? Which channels do they use, which challenges do they face? And how are they involved in the development of national strategies for social dimension? And after that: Which role do students' unions have in widening participation of underrepresented groups in higher education through their counselling activities? This paper provides an insight rather than a broad overview-because the challenges, opportunities, goals and disadvantages students' unions and counsellors meet in the various national contexts strongly differ.

\section{Underrepresented Groups in European Higher Education}

One of the main challenges for implementation of measures related to the inclusion of socially and culturally disadvantaged groups of higher education is that the understanding of underrepresented groups differs by country. Based on the definition used in the Eurostudent survey, we define them as a group which is not represented within the student population as it is in the general population (Hauschildt et al. 2015). Moreover, countries vary to a great extent in terms of monitoring participation of various student groups and the need for additional support. Most countries monitor participation and progress of students based on gender or disability, although disability is not defined the same way in many countries (e.g. if psychological disabilities are included or not). In some countries migrants and/or migrant children are considered important categories, while in other countries students with families are targeted (Weedon and Riddel 2012). From a student's perspective, the main groups underrepresented in higher education include students from low socio-economic background, students with physical disabilities and students with psychosocial disabilities/mental health issues. Other groups mentioned in many European countries include LGBTQ* students, students with children/dependents, students from immigrant background, students from different ethnic groups, specific gender of students, students with chronic health issues and mature students (ESU 2015). Eurostudent provides an overview of the educational background of students in the different Eurostudent countries. It shows in detail for example, that "underrepresentation of students without higher education background is apparent in almost all EUROSTUDENT countries" (Grabher et.al 2014).

Recently, the inclusion of migrants and refugees in higher education was discussed as an important issue in many European countries due to increasing worldwide mobility bringing more and more international students to European universities. Related to the social dimension, they have to overcome additional barriers and are affected by mechanisms other students don't have to face. "International students face the same life events and stressors as other students, but also additional pressures without the support system from friends and family home. The transition from one academic system to another can be confusing. Adjusting to 
a foreign culture can bring about a sense of loss in regard to native language, security and the self. Culture shock, loneliness, problems of language proficiency, financial dependency and expectations from the supporting families can increase the likelihood of developing mental health issues" (Rücker 2015).

The underrepresentation of specific groups does not only tackle higher education participation in general but also specific elements such as the internationalisation of higher education. For example, many disadvantaged student groups are underrepresented in mobility programmes as in the Erasmus+. To achieve higher participation from a more diverse student population in mobility, the Mobility and Internationalisation Working Group of the Bologna Follow-Up Group recommended in its report to develop a common understanding of underrepresented groups and each country should analyse the in-depth reasons for underrepresentation within the national context (EHEA 2015). However, groups underrepresented in mobility programmes do not necessarily match the underrepresented groups in national higher education systems (Grabher et al. 2014).

\section{Measures to Include Underrepresented Groups in European Higher Education}

Measures to widen participation in higher education have been taken in many European countries, including a number of mainstream-measures aiming for increase of participation as a whole, expecting to also increase the participation of underrepresented groups, as well as measures targeting specific groups directly. A more mainstream approach is undertaken by countries aiming for most accessible higher education for the widest range of learners, as for example education free of charge, grant and loan systems and high number of university places. Counselling is considered as one of the measures to widen participation in higher education, together with the provision of student facilities (e.g. housing, medical support, childcare). At the same time, many countries implement measures targeting underrepresented groups specifically, as for example students with disabilities, students from ethnic minorities or from socially and/or economically disadvantaged backgrounds (EACEA 2015).

Students' disadvantaged background is one of the main reasons for young people not to attend higher education. One reason for that can be explained by social capital theory (Bourdieu 1983), based on the idea that contacts or connections within and between social networks have an impact on individuals. For example, families with first-generation students can often provide less educational resources and support than academic families: they cannot help when deciding for a study programme, nor in case of difficulties with a professor or the question where to apply for grants. Counsellors can play an important role for students from disadvantaged backgrounds, as they can somehow compensate the lack of support other students might have from their family and friends (Pham and Keenan 2011). 
Other measures identified recently that enable students with low socio-economic background to participate in higher education is the introduction of alternative access routes, also mentioned in the 2012 Bucharest Communiqué. In many countries, the regular entry routes are defined by formal qualifications such as a higher education entrance degree or have access regulations such as exams or scoring based on school grades. While these regulations are considered a barrier for disadvantaged groups, many countries aim for providing alternative entrance routes, in order to compensate the imbalance between over- and under-represented groups. Also recognition of prior learning is considered an important tool to widen participation in higher education.

Dropout from higher education has a number of reasons, which might include psychological reasons, wrong choices of study programme, lack of financial resources. However, students from disadvantaged backgrounds are more likely to dropout. For example, in case of socio-economic disadvantaged backgrounds, students risk to drop out might be higher because of a lack of support from their families.

Counselling is one of the measures to reduce dropout in many countries. Other measures include additional financing or social support groups as well as student-centred teaching and learning approaches (ESU 2015). Reducing dropout and increasing completion rates in higher education is mentioned in one of the key strategies within the EHEA. Guidance of students, also when deciding their study programme is considered an effective tool to reduce dropouts. Students' expectations, commitment to the content of the programme as well as study programme expectations often differ from reality and lead to little satisfaction and often dropouts. Having the right image and realistic expectations is crucial to the probability of completing higher education successfully (Warps 2012). Counselling and guidance activities as career choice activities, visiting of future study programmes or matching activities support these choices (Mittendorff et al. 2017). Thus, better-informed students have more realistic expectations for their studies and are more satisfied with their choice because their expectations correspond to their experiences (Blüthmann 2012). This is why counselling plays such an important role in the decision-making process - not only for underrepresented groups but for them even more. Higher satisfaction means a higher chance to conclude the studies and therefore a lower rate of dropping out (Blüthmann 2012).

\section{Student Counselling as a Key Measure to Widen Access to Higher Education}

Counselling and guidance activities for students and prospective students are provided by diverse actors in Europe. There are many areas of counselling identified, such as educational guidance, career guidance, disability/equal opportunity guidance. While educational and career guidance is widely accepted and used by many 
students, services such as psychological counselling differ by country and also age of students. In countries where students enter higher education at a younger age (e.g. USA, UK, Ireland), psychological counselling is considered common for young people. In countries where students traditionally enter higher education at an older age, they are regarded as adults and expected to take care of themselves, (Rücker 2015) thus psychological counselling is often not provided for all students although there is a high number of students with psychological disabilities.

The way counselling is organised, the level of competence and qualifications of counsellor differ greatly from sector to sector, from institution to institution and from country to country (Rücker 2015). While in some countries, universities have an obligation to provide counselling, in other countries many private associations or NGOs provide counselling to students, especially in countries with high demands to access higher education. In other cases organisations aiming for support of specific student groups and/or disadvantaged or underrepresented groups provide specific counselling. This often does not include only provision of information but also support in difficult situations (e.g. where students are affected by harassment) as well as provision of a peer-network. For example, these activities are provided for female students in STEM programmes, older students, LGBTQ students or students with children.

In many countries counselling and guidance is provided by students' unions. However, the approaches of students' unions differ as well as the specific measures undertaken. In most cases counselling activities by students' unions are based on the concept of peer counselling. Students providing guidance for other students or prospective students has many advantages, often meaning that counselling is provided on a level playing field. All those involved live in a similar environment, often taking part in the same study programme. They experience similar difficulties and challenges and counselling often includes an exchange of good practices on how to overcome these. At the same time, peer counselling comes with difficulties: many of the counsellors are volunteers and provide their services in their free time. Thus, the quality of counselling is diverse and based on the individual's engagement in learning e.g. about legal backgrounds and other counselling opportunities. In many cases, the students' union provides trainings and/or documents and information materials to overcome this issue. Another challenge is the lack of professional counsellors and/or supervisors. Not all questions can be answered within peer counselling alone. A network of professionals who can support students is important, but often not possible because counselling activities may lack funding. In some cases students' unions are able to provide funding for legal or psychology professionals who can support student counsellors or students if required.

Another challenge for students' unions is that they do not only aim to solve individual student issue but identify a political solution to problems encountered by the overall student population. Thus, provision of counselling is often considered an conflicting area, as the problems identified during counselling are also used to make political claims. with making political use out of the problems identified during counselling activities (Wilhelm 2013). 
The diverse types of counselling provided by students' unions make it difficult to compare them in terms of effectiveness also because little data is available. But results from Germany and Austria tend to show that counselling activities provided by student unions are helpful to students. In a representative study in Germany, 74 percent of the students who took advantage of student union counselling activities perceived it as useful (Ortenburger 2013). In the nation-wide Social Survey 2015 in Austria, two out of the top three rated counselling activities are provided by the Austrian Students' Union. Besides counselling activities, mentoring and tutoring by peers is also a common activity by students' union. As there is no data on the specific mentoring programmes, they are seen as a successful measure to prevent dropouts. As Cullen wrote "[...] a number of studies suggest that institutions that adopt peer and mentoring support programmes have lower rates of dropout" (Cullen 2013).

\section{What Kind of Counselling Is Provided by Students' Unions in Europe?}

To learn about different approaches to student counselling provision in Europe, nine countries were selected for an in-depth analysis to identify current practices in student counselling by students' unions, based on geographical diversity. The data was gathered by an online survey sent to the national students' unions of the respective countries, desk research and follow-up telephone interviews with student representatives in the nine countries analysed.

Students' unions follow diverse approaches regarding counselling activities. While some unions consider the provision of counselling as one of their major tasks, others are not involved in counselling activities at all. The approach followed by the students' unions is influenced by the traditional self-understanding of their role. Some unions consider themselves more as a political actor in the academic and/or public sphere, others consider the provision of services to students as their core activity. Counselling activities are also a question of resources. Many students' unions do not have financial resources to provide counselling to students for example by hiring professionals. Other students' unions dedicate their staff resources to other issues, as they are considered more urgent. For example, in the UK counselling is provided mostly by universities, while the students' unions focus more on academic representation and raising awareness on issues such as student welfare and support for student groups experiencing discrimination: women, black and minority ethnic students, disabled students and LGBTQ students. Another reason for students' unions not to engage in student counselling is the political environment. For example, with the ongoing crisis in Spain, the students' unions focus on the struggle against raising tuition fees and financial cuts to scholarships, although counselling activities are considered important in the future. 
But also, unions which provide counselling activities struggle with the available resources. For example, in Italy, counselling is mainly provided by student volunteers while there is a lack of resources for the organisation of counselling, as paid staff or counselling offices. In Germany and Austria, the expansion of psychological student counselling was identified as not satisfactory at the moment. In total three of the students' unions in the nine countries analysed do not provide student counselling due to the reasons described. Six unions provide counselling activities.

Counselling activities provided by the students' unions vary. The Lithuanian students' union provides general counselling for individual students, which might range from student loans and scholarships to the quality of student housing. The German students' union only counsels few individual cases at national level, which are specifically brought to their attention, while the main counselling activities are provided by the unions at institutional level. The fzs (Germany) provides specific counselling to students who have problems in finding a study place matching their preferences because of restricted access. A specific website was developed to enable the exchange of study places among students (Fig. 1).

In Italy, Slovenia and Austria counselling provided by the students' unions is diverse and covers a number of activities. This includes counselling of prospective students on entering higher education and choosing a specific study programme. The Austrian Students' Union provides counselling for prospective students also in schools and organises a peer-counselling programme, where prospective students join a student to attend lectures and can ask questions afterwards. The Italian students' union organises guided tours by their local unions, providing background information about the university to new students with a focus on local specifics, services offered and unions as well as student rights. The Slovenian students' union (SSU) attends higher education fairs, providing specific information via website and

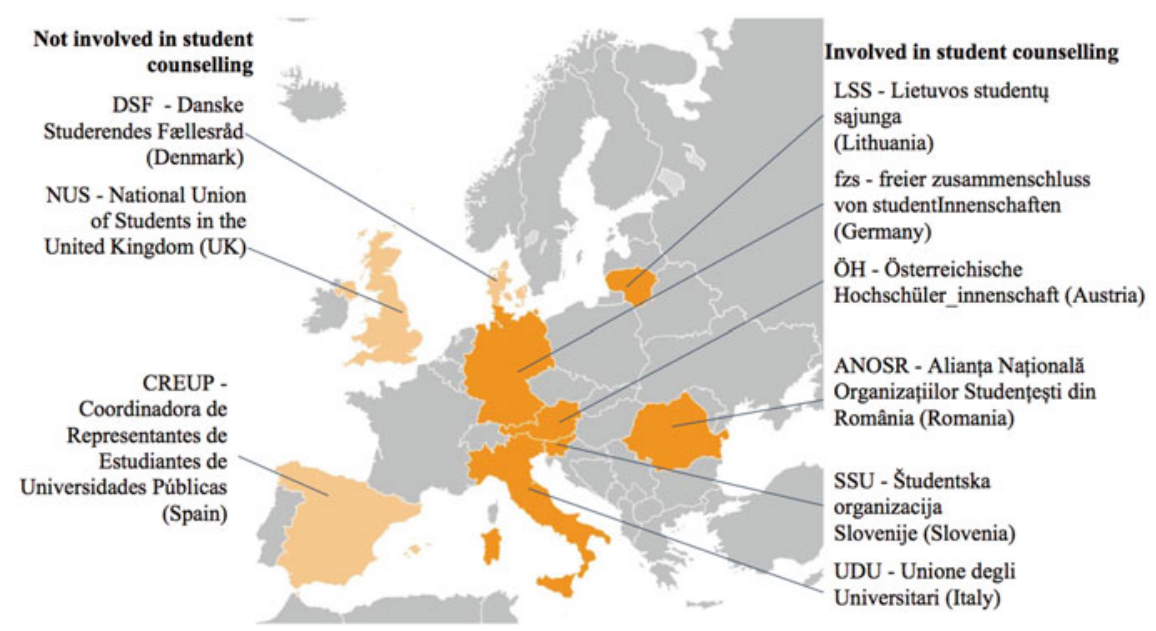

Fig. 1 Students union involvement in student counselling. Source Online survey; $n=9$ 
email. The Italian and the Austrian unions both offer regular counselling at national and local level on diverse issues. The Austrian union also provides online counselling through a chat programme as well as counselling for specific topics such as accessibility and barrier-free education, social affairs, foreign students and higher education regulations. In Romania the students' union (ANOSR) was actively involved in the development of the methodology provided by Counselling and Career Orientation Centres, which was adopted in October 2014 by Order of the Ministry of Education. These measures were, nonetheless, not put in practiceaccording to the union, due to inadequate funding.

Students' unions do not only provide general counselling but also counselling for specific target groups, underrepresented in higher education. The target groups approached differ by country. While most target disabled students and students with mental disabilities, working students and students facing financial difficulties, care obligations and gender issues are not tackled by all unions specifically. Target groups such as first-generation students, non-traditional students, migrants and students from developing countries, or students with migrant background are provided with specific counselling by only half of the unions analysed.

Three students' unions (in Lithuania, Denmark and Austria) also reported providing mentoring and tutoring to (prospective) students. This is organised and implemented by local students' unions which organise the mentoring programmes and match the mentors with prospective and/or first-year students (Fig. 2).

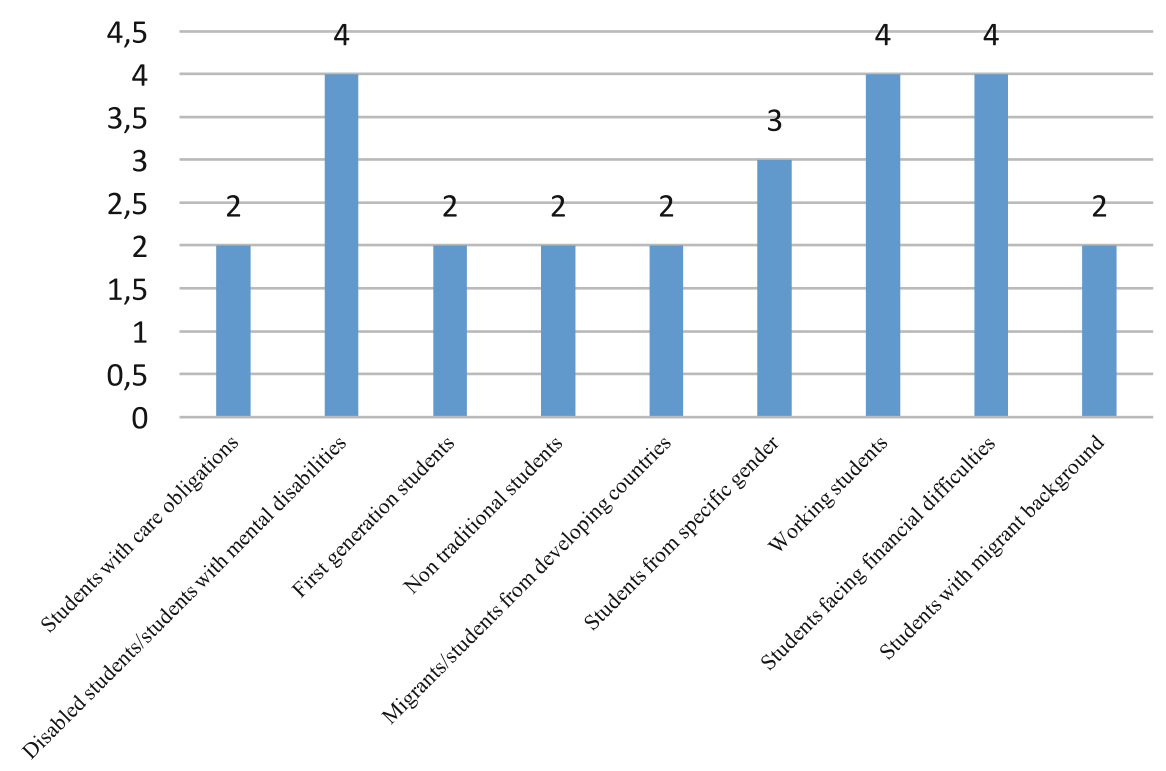

Fig. 2 Counselling activities for specific target groups. Source Online survey; $\mathrm{n}=9$ 
Many students' union cooperate with other organisations in order to provide counselling to students, especially when it comes to specific issues such as housing, law or working students.

The Lithuanian students' union often cooperates with youth organisations. The German students' union cooperates with tenants' unions in housing issues, with higher education groups of the federal trade union (DGB) or local lawyers associations. The UK students' union works with the Child Poverty Action group to produce a yearly advice book on student finance and cooperates with other organisations providing advice and guidance to students, in order to exchange good practices and the impact of legislation on students. The Italian students' union collaborates with the high school students' union (Rete degli Studenti Medi) to provide counselling to students in their last year of upper secondary education. They also work with the trade union (CGIL) to support working students, as well as with LGBT organisations (e.g. Arcigay).

The Austrian students' union cooperates with the Ministry of Science, which funds counselling activities for prospective students. Other cooperation takes place by exchange of experiences and best practices with the federal Psychological Counselling Service, the department for study grants and higher education institutions. Two unions (SSU in Slovenia and ANOSR in Romania) cooperate with representative bodies: SSU reported cooperation depending on the target groups, whereas ANOSR cooperates and meets regularly with the Romanian Youth Council and the National Council of Students. ANOSR and ÖH (Austria) reported cooperation with the responsible ministry and other institutions which provide student counselling (Fig. 3).

Students' unions describe that most counselling activities take place regularly face-to-face, via phone and by e-mail. Face-to-face counselling is considered the most useful way, as students often feel more comfortable by meeting a peer-counsellor and issues can be discussed in more detail. E-mail and social media conversation are also often used to arrange a face-to-face meeting or to direct students to the most appropriate counsellor in case of specific questions (Fig. 4).

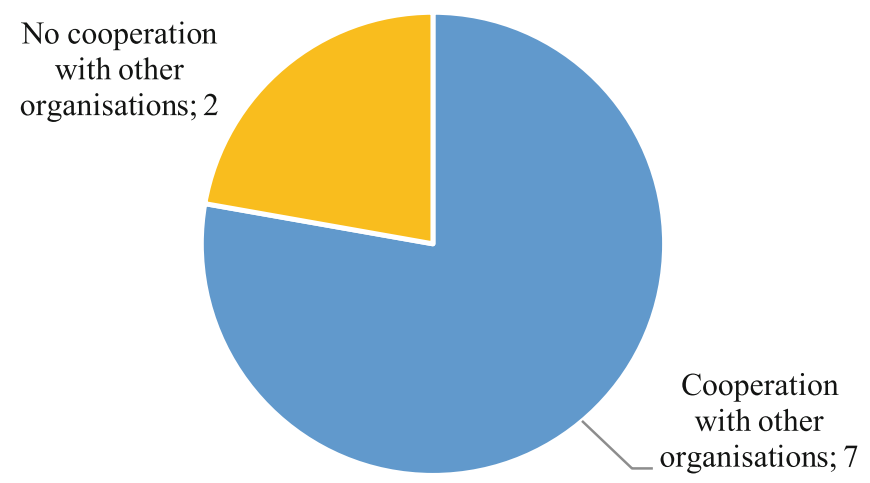

Fig. 3 Cooperation with other organisations. Source Online survey; $n=9$ 
Fig. 4 Communication channels used for counselling activities. Source Online survey; $\mathrm{n}=9$

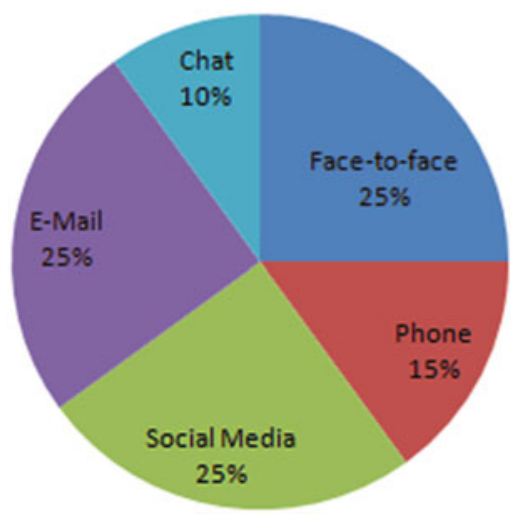

The use of social media in student counselling was mentioned by all unions. Social media is considered an additional way of counselling, for example using the Facebook chat. One union reports the growing use of virtual communication (e-mail or social media). Also, other chat programmes, such as WhatsApp or Telegram, were mentioned amongst used communication tools. They are considered helpful as they provide quick, informal counselling for some questions or help schedule face-to-face meetings.

Individuals providing counselling to students have diverse backgrounds, however in most cases, counselling is provided by student peers. This is considered helpful by many students' unions, as peer counselling lowers the barrier to ask "silly" questions and counsellors know the living and studying situation from their own experience. However, some students' unions also employ professional counsellors. When it comes to legal issues, professionals with a background in law, often specialised in higher education law, are employed. In some cases, professional counsellors, as educational counsellors with a background in social sciences or psychologists are employed, for example to support prospective students in the selection process of their desired study programme or to support students in psychological crisis.

Counselling is provided mostly on a regular basis. There are daily or specified opening hours (e.g. 2-3 times a week). In two of the analysed cases, counselling is available on a non-regular basis, upon demand of students (Fig. 5).

\section{Students' Involvement in the Development of National Strategies for Social Dimension}

The social dimension of higher education is considered of different importance in the European countries. Within the "Bologna with student eyes" survey, students' unions considered the social dimension as a high priority in only eight countries 
Fig. 5 Background of counsellors. Source Online survey; $\mathrm{n}=9$

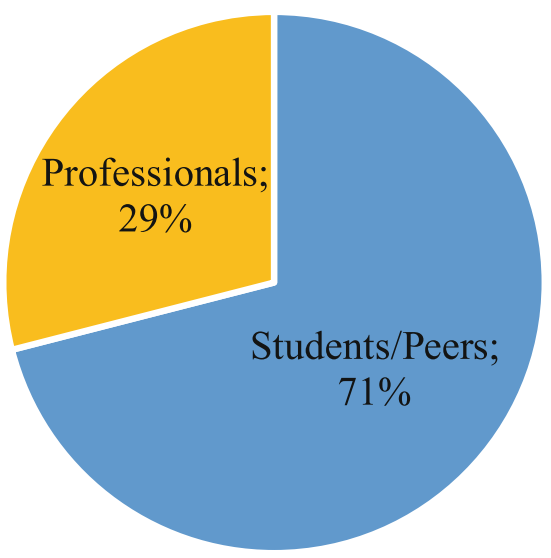

(out of 36 Bologna countries) and many reported they perceived students as the only stakeholders interested in taking action in the field of social dimension.

Since the Bucharest Communiqué (2012), countries are encouraged to develop national access plans to widen participation in higher education. In 2015, access plans were successfully implemented in two countries, six were struggling with proper implementation of action plans, ten countries were debating implementation of an action plan and 13 countries did not debate it until that moment (ESU 2015). However, it seems that several countries started to work on the implementation of a strategy to widen participation in higher education since then.

Nearly all students' unions interviewed for this analysis, with one exception, are involved in the development of a national strategy for social dimension in their country. The development of national strategies for widening access to higher education differs by country. While some countries have strategies already implemented, others are in the early stages of this process.

The involvement of students in the process of developing a strategy for widening access differs by country. However, in most countries, students' unions are critical about the outcomes and not satisfied with the measures described in the strategy.

In Lithuania, no strategy on social dimension is in place yet, but there are ongoing working groups involving the students' union. The Spanish students' union takes part in the consultation process, but has a critical perspective on the process and is not satisfied with the results yet. In Germany, the students' union is involved in related working groups and the legislative procedures. However, due to the German structure of regional responsibility for education, no national strategy is in place. Also in the UK, there are regional differences, however, all four administrations have been focussed on policies relating to the student dimension and as a national representative organisation, the students' union is consulted and has an input into proposed legislation on widening access. The students' union is involved in commissions and implementation groups of access plans and is very active in identifying barriers to different student groups and raising awareness about the 
social dimension. In Italy the students' union is involved in the process to develop the national strategy on the social dimension as a consultant body. However, the students' union is not satisfied with their involvement in the process so far. The Austrian students' union is not satisfied with the outcomes of the process to develop a strategy for widening access to higher education. They were involved in the consultation process within several workshops, but do not consider their recommendations adequately represented in the final outcome. The Slovenian students' union is fairly satisfied with the outcome of its involvement - the union reports being part of all task forces and participating in negotiations reminding the others about the importance of the social dimension. In Romania, the students' union started to campaign for social dimension issues in 2016, demanding public funding and other goals for higher education development for the election cycle 2016-2020. As a result of ANOSR's commitment, the student scholarship fund increased by 142\% between January and March 2017 and the students benefit from free train transportation throughout the year, with all types of trains. ANOSR has requested specific increases for different budget chapters such as basic funding for scholarships, investment funds in higher education, subsidy for transport or canteens, etc. The only students' union which is not actively involved in the development of national strategies regarding the social dimension is the Danish one.

\section{Conclusions}

The analysis of student' union involvement in student counselling and guidance activities identifies a number of good practices supporting underrepresented groups in higher education. Counselling and guidance are considered highly important when it comes to widening access to higher education and support for disadvantaged students.

Students' unions are well aware of the social dimension of higher education and aim to provide services and engage in policy-making to achieve a more diverse student population, which includes negotiations with responsible stakeholders and policymakers while also campaigning and lobbying. However, the approaches used differ by students' union. While some unions consider the provision of counselling and guidance as one of the main pillars to support disadvantaged students on their way to higher education and successful completion of their studies, other unions are more active in policy-making and consider counselling mainly a responsibility of universities and other organisations.

For those students' unions involved in counselling and guidance activities, the peer learning approach has proven specific relevance. The contact on a level playing field as well as the communication tools used (e.g. social media, chat, e-mail) reduce barriers for (prospective) students. Especially in cases where counsellors are also role models from underrepresented groups, the peer counselling is effective, as counsellors and students share similar experiences. 
However, students' unions also identify challenges when it comes to peer counselling activities. For example many of them lack the necessary resources and funding to provide adequate counselling involving professional supervisors or professional counsellors. Moreover, sometimes they lack infrastructure and professional training. Another point mentioned by both students' unions and relevant literature is the lack of data on underrepresented groups in higher education. At the same time some students' unions face restrictions and higher education reforms such as stricter study plans with less individual choices and flexibility, reforms which link grants to a certain study progress and similar issues.

Counselling activities offered by students' unions fill a gap: on one hand, most of them cooperate with other organisations and, on the other hand, students or prospective students are less hesitant in asking for help. So, students' unions often interact with those who might not get in contact with specialised organisations. From this perspective, students' unions have to be all-round talents in their counselling offers: different target groups, different issues, different channels. However, in a certain way, they are also the connecting "glue" between specialised counselling offers due to their cooperation with responsible organisations or stakeholders.

The role of counselling activities for widening access and creating an inclusive higher education system, as well as for reducing dropouts from higher education was mentioned by several documents and authors. Following the Ministerial Communiqués of recent Ministerial Conferences, many countries aim for the implementation of a social dimension strategy or national access plans. While students unions are involved in the development of these strategies, many of them are not satisfied with the process and/or its outcomes yet, although it will be a crucial point for the successful further implementation of the Bologna Process that aims for a more diverse student population.

\section{References}

Blüthmann, I. (2012). Individuelle und studienbezogene Einflussfaktoren auf die Zufriedenheit von Bachelorstudierenden. ZfE 2012, Verlag für Sozialwissenschaften, 15(2), 273-303.

Bourdieu, P. (1983). Ökonomisches Kapital, kulturelles Kapital, soziales Kapital. In K. Reinhard (Ed.), Soziale Ungleichheiten. Soziale Welt Sonderband 2. Göttingen.

Conference of Ministers Responsible for Higher Education. (2001). Towards the European higher education area. In Communiqué of the Conference of Ministers Responsible for Higher Education in Prague on May 19, 2001.

Conference of Ministers Responsible for Higher Education. (2007). London Communiqué towards the European higher education area: Responding to challenges in a globalized world.

Conference of Ministers Responsible for Higher Education. (2012). Making the most of our potential: Consolidating the European higher education area. Bucharest Communiqué.

Conference of Ministers Responsible for Higher Education. (2015). Yerevan Communiqué.

Cullen, J. (2013). Guidance for inclusion practices and needs in European universities. STAY IN Consortium. 
European Commission. (2014). Taking stock of the Europe 2020 strategy for smart, sustainable and inclusive growth. COM (2014) 130 final, Brussels, 2014.

European Commission/EACEA/Eurydice. (2015). The European higher education area in 2015: Bologna process implementation report. Luxemburg: Publications Office of the European Union.

European Higher Education Area. (2015). Report of the 2012-2015 BFUG working group on mobility and internationalisation. Brussels.

European Students' Union. (2015). Bologna with student eyes 2015. Time to meet the expectations from 1999. Brussels: European Students' Union.

Grabher, A., Wejwar, P., Unger, M., \& Terzieva, B. (2014). Student mobility in the EHEA. Underrepresentation in student credit mobility and imbalances in degree mobility. Project Report. Synopsis of Indicators. EUROSTUDENT V. Bielefeld: Bertelsmann.

Hauschildt, K., Gwosć, C., Netz, N., \& Mishra, S. (2015). Social and economic conditions of student life in Europe: Synopsis of indicators. Eurostudent V 2012-2015. W. Bertelsmann Verlag. https://doi.org/10.3278/6001920bw.

Mittendorff, K., Faber, M., \& Staman, L. (2017). A matching activity when entering higher education: Ongoing guidance for the students or efficiency instrument for the school? British Journal of Guidance and Counselling, 45(4), 376-390.

Ortenburger, A. (2013). Beratung von Bachelorstudierenden in Studium und Alltag. Ergebnisse einer HISBUS-Befragung zu Schwierigkeiten und Problemlagen von Studierenden und zur Wahrnehmung, Nutzung und Bewertung von Beratungsangeboten (pp. 73-80). HIS: Forum Hochschule.

Pham, C., \& Keenan, T. (2011). Counseling and college matriculation: Does the availability of counseling affect college-going decisions among highly qualified first-generation college-bound high school graduates? Journal of Applied Economics and Business Research, 1, 12-24.

Riddell, S., \& Weedon, E. (2014). European higher education, the inclusion of students from underrepresented groups and the Bologna process. International Journal of Lifelong Education, 33(1), 26-44.

Rücker, H. (2015). Students' mental health and psychological counselling in Europe. Berlin: Mental Health \& Prevention, 3 34-40.

Vukasovic, M. (2017). Stakeholder organizations in the European higher education area: Exploring transnational policy dynamic. Policy and Society, Routledge Tayler \& Francis Group, 36(1), 109-126.

Warps, J. (2012). Adviezen voor studiekiezers op basis van de Startmonitor Conclusies en aanbevelingen op basis van jaarlijks onderzoek naar studiekeuze en studiesucces. Nijmegen: Researchned.

Weedon, E., \& Riddel, S. (2012). Reducing or reinforcing inequality: Assessing the impact of European policy on widening access to education. In S. Riddel, J. Markowitsch, \& E. Weedon (Eds.), Lifelong learning in Europe. Bristol: Policy Press.

Wilhelm, D. (2013). Möglichkeiten und Grenzen von Peer-Angeboten in der Studieneingangsphase - Herausforderungen der studentischen Lebensphase und Reaktionen der Beratungsinstitutionen an Hochschulen. In K. Manfred (Ed.), Zeitschrift für Beratung und Studium. Handlungsfelder, Praxisbeispiele und Lösungskonzepte. Bielefeld: Universitätsverlag Weber. 
Open Access This chapter is licensed under the terms of the Creative Commons Attribution 4.0 International License (http://creativecommons.org/licenses/by/4.0/), which permits use, sharing, adaptation, distribution and reproduction in any medium or format, as long as you give appropriate credit to the original author(s) and the source, provide a link to the Creative Commons license and indicate if changes were made.

The images or other third party material in this chapter are included in the chapter's Creative Commons license, unless indicated otherwise in a credit line to the material. If material is not included in the chapter's Creative Commons license and your intended use is not permitted by statutory regulation or exceeds the permitted use, you will need to obtain permission directly from the copyright holder.

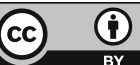

